\title{
Molecular and Clinical Insights on the Complex Interaction between Oxidative Stress, Apoptosis, and Endobiota in the Pathogenesis of Endometriosis
}

\author{
Bogdan Doroftei ${ }^{1,2,3}$ (), Ovidiu-Dumitru Ilie ${ }^{4, *}$ (D) , Ioana-Miruna Balmus ${ }^{5}$, Alin Ciobica ${ }^{4}$, Radu Maftei ${ }^{1,2,3}$, \\ Ioana Scripcariu ${ }^{1}$, Gabriela Simionescu ${ }^{1,2,3}$, Delia Grab ${ }^{1,2}$, Irina Stoian ${ }^{1, *}$ and Ciprian Ilea ${ }^{1,2}$ \\ 1 Faculty of Medicine, University of Medicine and Pharmacy “Grigore T. Popa”, University Street, no 16, \\ 700115 Iasi, Romania; bogdandoroftei@gmail.com (B.D.); dr.radu.maftei@gmail.com (R.M.); \\ isscripcariu@gmail.com (I.S.); gabi.ginecologie@gmail.com (G.S.); delianicolaiciuc@yahoo.com (D.G.); \\ cilea1979@yahoo.com (C.I.) \\ 2 Clinical Hospital of Obstetrics and Gynecology "Cuza Voda”, Cuza Voda Street, no 34, 700038 Iasi, Romania \\ 3 Origyn Fertility Center, Palace Street, no 3C, 700032 Iasi, Romania \\ 4 Department of Biology, Faculty of Biology, "Alexandru Ioan Cuza" University, Carol I Avenue, no 20A, \\ 700505 Iasi, Romania; alin.ciobica@uaic.ro \\ 5 Department of Interdisciplinary Research in Science, "Alexandru Ioan Cuza" University, Carol I Avenue, \\ no 11, 700107 Iasi, Romania; ioana.balmus@uaic.ro \\ * Correspondence: ovidiuilie90@yahoo.com (O.-D.I.); Stoian.irinalv@gmail.com (I.S.)
}

Citation: Doroftei, B.; Ilie, O.-D.; Balmus, I.-M.; Ciobica, A.; Maftei, R.; Scripcariu, I.; Simionescu, G.; Grab, D.; Stoian, I.; Ilea, C. Molecular and Clinical Insights on the Complex Interaction between Oxidative Stress, Apoptosis, and Endobiota in the Pathogenesis of Endometriosis. Diagnostics 2021, 11, 1434. https:/ / doi.org/10.3390/diagnostics11081434

Academic Editor: Antonio

Simone Laganà

Received: 28 June 2021

Accepted: 6 August 2021

Published: 9 August 2021

Publisher's Note: MDPI stays neutral with regard to jurisdictional claims in published maps and institutional affiliations.

Copyright: (c) 2021 by the authors. Licensee MDPI, Basel, Switzerland. This article is an open access article distributed under the terms and conditions of the Creative Commons Attribution (CC BY) license (https:/ / creativecommons.org/licenses/by/ $4.0 /)$.

\begin{abstract}
Endometriosis (EMS) remains, to date, an intriguing and debilitating gynecological disorder that possesses a multifactorial substrate. Recent studies with the objective of elucidating its etiology highlighted the antagonistic effect of EMS on a multiple of processes involved in homeostasis. Although the current oxidative biomarkers clearly reveal the consequences induced by EMS, its implication in the associated inflammatory reactions could be much more complex. Besides the overproduction of reactive oxygen species (ROS) that leads to an exacerbated oxidative response, it also changes the normal expression of several pro-inflammatory modulators, reflected by the fluctuating activity of several pro- and anti-apoptotic mediators whose expression is impaired. In light of this topic, several studies elucidate the involvement of apoptosis in EMS, being brought controversial findings, even reports with no significant change. Further, some authors reported an abnormal expression of multiple genes that are crucial for the overall functionality of the female reproductive system. Cumulatively, it seems that the subsequent oxidative imbalance and apoptosis process impairment could further disrupt the normal removal of unnecessary biological products. Based on all gathered evidence, we could argue that the related stress state could determine human endobiota impairment, which could further participate in the inflammatory and main antioxidant enzyme changes occurring in EMS. Moreover, a correlation between endobiota integrity, inflammation, and oxidative stress (OS) was suggested in relation to the possible predisposition to pathogen determined infections.
\end{abstract}

Keywords: endometriosis; oxidative stress; apoptosis; vaginal microbiota; virome

\section{Introduction}

EMS is a common and enigmatic hormone-dependent gynecological disorder clinically described first in the 1920s. Even though more than one hundred years have passed since it was documented for the first time, its etiology still raises debate and controversy [1]. Clinically, EMS is defined as the presence of vascularized endometrial-like glandular tissue dispersed at ectopic sites and stroma outside the uterus. Despite the occurrence of these lesions within the peritoneal cavity (bladder, ovaries, colon, or peritoneum wall), the latest reports indicate the presence of such structures in the liver, lung, and brain as well $[2,3]$. 
Left untreated, EMS causes severe primary dysmenorrhea, chronic pelvic pain, dyspareunia, and infertility [4]. According to the latest issued figures, more than one hundred million women of reproductive age suffer from EMS (between 5-15\% females worldwide). Approximately 90\% report menstrual reflux, while 5-10\% develop EMS [5].

It has been theorized to originate from endometrial fragments shed during menstruation. These lesions reach the peritoneal cavity via the Fallopian tubes, a process that is known as "retrograde menstruation" [6]. However, of the multitude of hypotheses that have been proposed in recent years-immune and stem cell dysfunction, embryonic rest, and coelomic metaplasia [7-9] - Sampson's theory of retrograde menstruation remains the most solid argument of the origin of EMS to date $[2,6,10,11]$.

Halme et al. suggested that most of the women display some degree of reflux of endometrial debris [12]. This argument is supported by the cumulative evidence according to which menstrual effluents could retrogradely scatter into the peritoneal cavity carrying viable endometrial cells [13-17].

Besides the standard clinical panel, EMS-diagnosed women are also at higher risk of developing autoimmune, cardiovascular, or gastrointestinal diseases and cancer [18]. From a mechanistical point of view, EMS could impair the apoptotic process, which could explain the abnormal cytokine storm and abnormal oxidative stress (OS) profile [19].

A disruption of the internal microenvironment could subsequently cause microbiome dysbiosis (e.g., pro-inflammatory cascades). With respect to the plethora of roles of the microbiome in various pathologies [20], endobiota could be the missing link. In this regard, Khan et al. 2018 discussed the new hypothesis known as "bacterial contamination" [21].

Considering the complex mechanisms underlying EMS development and the multiple hypotheses of pathological processes leading to EMS occurrence, we aimed to evaluate the possible relevance of OS, apoptosis, and dysbiosis in EMS. In this way, it is our goal to describe several mechanisms that can elucidate the outcomes and correlation of these particular processes.

\section{Materials and Methods}

For this work, literature searches were conducted independently using the main scientific databases (Web of Science, Scopus, Google Scholar, Science Direct, Cochrane Database for Systematic Reviews, PubMed/Medline). The initial information acquisition was based on database search using keywords such as "endometriosis", "oxidative stress", "apoptosis", "endobiota", "vaginal microbiota", "cervical microbiota", "gut microbiota", "animal models", and "human/patients" in all the relevant combinations. In the second step of selection, all the relevant literature up until June 2021 was categorized based on title, abstract content, and full content, and only the English written articles were further considered. Eight authors (O.-D.I., I.-M.B., R.M., I.S., G.S., D.G. and I.S.) independently inquired the information, with any differences in opinion being solved by common consent with the remaining three authors (B.D., A.C. and C.I.).

Based on all studies selected, in two tables (Tables 1-3), we present all main features that define each study.

\section{Oxidative Stress and EMS}

\section{Oxidative Stress and EMS}

The implication of OS in EMS was previously described by several studies, which both addressed the screening of OS markers in EMS patients and mechanistical approaches in EMS animal models. In this way, the screening studies showed that several important oxidative markers are modified in EMS patients suggesting that OS could be an important component underlying and/or promoting EMS tissular damage. However, since correlation could not always imply causation, the way in which OS and EMS interact was not yet fully understood.

For instance, several studies showed that the typical OS markers changes suggest that EMS's antioxidant defense could be impaired. Amreen et al., [22] reported that both 
superoxide dismutase (SOD) and glutathione peroxidase (GPx) antioxidant activities are significantly decreased in the blood and peritoneal fluid of EMS patients, while Turkyilmaz et al. [23] also found catalase (CAT) activity increased in the serum of 31 EMS-diagnosed women. Moreover, they showed that the pattern in which antioxidant enzymes activity varied is in direct correlation to EMS severity. Furthermore, it was demonstrated that non-enzymatic antioxidants, such as vitamin $\mathrm{C}$, vitamin $\mathrm{E}$, and native and total thiols, are significantly less present in the blood of EMS patients [23,24].

Regarding the effects of ROS production and accumulation in EMS, it was described that the decrease of antioxidant defense could further lead to significant molecular and tissular damage. It was shown that OS could have negative implications on proteins, lipids, and DNA [25]. While Alizadeh et al. [26] found no significant increase in lipid peroxidation (malondialdehyde-MDA) and protein peroxidation markers (carbonyls) in the blood of EMS patients, nor did Elsharkawy et al. [24] in the blood and follicular fluid (FF) of infertile EMS-diagnosed women, other studies bring relevant evidence of molecular damage following oxidative balance impairment. Thus, Nasiri et al. [27] recently evaluated lipid peroxides (LPO) and total antioxidant capacity (TAC) in the serum and FF of women with EMS and reported significantly increased LPO, concomitant with decreased TAC in both fluids, as compared to healthy control women.

However, a correlation between systemic and peritoneal oxidative biomarkers could not be established following Montoya-Estrada et al.'s [28] study in which increased levels of carbonyls and LPO were found in EMS patients peritoneal fluid, while other protein oxidation product (protein dityrosine) levels were increased in the blood, as compared to the control group. Despite the fact that no correlation was found between the hemoglobin content of the peritoneal fluid and carbonyls and LPO and between the OS markers from blood and peritoneal fluid, the study reported a significant increase of MDA levels in the latter, suggesting that, together with the ischemia-modified albumin levels increase, oxidative balance impairment could play a determinant role in EMS-related tissular damage and a possible correlation in the co-occurring pro-inflammatory processes. In this regard, it was shown that several inflammation-related molecules are also regulated dependently or independently of ROS production and accumulation. Thézénas et al. [29] identified amine oxidase 3 and vascular adhesion protein 1 (AOC3/VAP1), in particular alkenal reductase PTGR1 and methionine sulfoxide reductase, as candidates for altered ROS landscape in EMS and possibly influencing the systemic and/or local inflammatory response. Furthermore, they observed important molecular changes in the ectopic lesion (such as iron overload, increased ROS production, and lipid peroxidation) and noted that ROS-derived 4-hydroxy-2-nonenal (4-HNE) over-production led to monocytic interleukin IL-8 release.

The implication of iron in the OS modulation occurring in EMS was also previously suggested on several occasions. In this way, Alizadeh et al. [26] showed that serum iron levels in patients with EMS were significantly increased and suggested that this metal ions could be a potent promoter of OS in EMS. The accumulation of iron ions was also reported by Polak et al. [30] while studying the overall oxidative status of peritoneal fluid of EMS patients suggesting that iron metabolism could be disrupted in this disease. Furthermore, since iron could catalyze many ROS species production and was also implicated in cellular dysfunction, necrosis, and apoptosis, Chen, Hayashi, and co-authors [31,32] investigated the mitochondrial structure and function of endometrial stromal cells (ESCs) in ovarian endometriosis (OE) in relation to mitochondrial and iron metabolism. They found that in the ESCs, mitochondria generated more ROS, while SOD2 was highly expressed in the endometrium, suggesting an abnormal energetic metabolism of ectopic ESCs. SOD2 promoted two distinct processes: Cell proliferation and migration in OE. Furthermore, in an OE murine model, concomitant with the iron accumulation and proteins and DNA alterations due to OS, as evaluated through the levels of 4-NHE and 8-hydroxy-2'-deoxyguanosine (8-OHdG), specific lesions were observed in the intestine, pancreas, and peritoneal wall, and time-dependent ovarian fibrosis development. Further evaluation of fibrotic tissue development in EMS in correlation with OS occurrence was conducted by González-Foruria 
et al. [33] who described the possible mechanism in which OS may also be implicated in ADAM17/Notch signaling pathway modulation culminating with fibrosis development. They showed that in deep infiltrating endometriosis (DIE), a direct correlation was observed between ADAM17 protein levels and increased advanced oxidation protein products (AOPPs) in the ectopic lesions, as well as the fact that the expression of Notch was abnormal for type-I collagen, which suggested fibrosis development.

Table 1. Summary content regarding the outcomes in which we investigated the oxidative and potential biomarkers.

\begin{tabular}{|c|c|c|c|c|}
\hline Subject & Number & $\begin{array}{l}\text { Type of } \\
\text { Sample }\end{array}$ & $\begin{array}{l}\text { Biomarker of } \\
\text { Interest }\end{array}$ & Reference \\
\hline Female & 18 EMS patients & $\begin{array}{l}\text { Ectopic and } \\
\text { eutopic } \\
\text { samples }\end{array}$ & $\begin{array}{c}\text { Novel OS biomarker- } \\
\text { AOC3/VAP1, } \\
\text { alkenal reductase } \\
\text { PTGR1 and methionine } \\
\text { sulfoxidereductase }\end{array}$ & [29] \\
\hline Female & $\begin{array}{l}133 \text { women; } 40 \\
\text { ectopic and } 73 \text { eutopic }\end{array}$ & Ectopic ESCs & $\begin{array}{c}\text { Ectopic ESC ROS } \uparrow \\
\text { SOD2 } \uparrow\end{array}$ & [31] \\
\hline Female & $\begin{array}{l}55 \text { EMS patients out of } \\
64\end{array}$ & $\begin{array}{c}\text { Blood and } \\
\text { peritoneal fluid }\end{array}$ & $\begin{array}{l}\text { SOD } \downarrow \\
\text { GPx } \downarrow\end{array}$ & [22] \\
\hline Female & $\begin{array}{l}28 \text { EMS patients and } 23 \\
\text { controls }\end{array}$ & $\begin{array}{c}\text { Plasma and } \\
\text { peritoneal fluid }\end{array}$ & $\begin{array}{c}\text { Carbonyl } \uparrow \\
\text { LPO } \uparrow\end{array}$ & [28] \\
\hline Female & $\begin{array}{l}121 \text { EMS patients and } \\
81 \text { controls }\end{array}$ & Peritoneal fluid & $\begin{array}{c}\text { AOPP } \uparrow \\
\text { ADAM17 } \uparrow \\
\text { Notch } \uparrow\end{array}$ & [33] \\
\hline Female & $\begin{array}{l}110 \text { EMS patients and } \\
119 \text { with benign } \\
\text { ovarian cysts }\end{array}$ & Peritoneal fluid & $\begin{array}{c}\text { Haemoglobin } \uparrow \\
\text { Iron } \uparrow \\
\text { TOS } \uparrow \\
\text { TAS } \downarrow\end{array}$ & {$[30]$} \\
\hline Female & $\begin{array}{l}30 \text { EMS patients and } 30 \\
\text { controls }\end{array}$ & Follicular fluid and serum & $\begin{array}{c}\text { Vitamin } C \downarrow \\
\text { Vitamin } \mathrm{E} \downarrow \\
\operatorname{SOD} \uparrow \\
\operatorname{MDA} \neq\end{array}$ & [24] \\
\hline Female & 63 EMS patients & Follicular fluid and serum & $\mathrm{LPO} \uparrow \mathrm{TAC} \uparrow$ & [27] \\
\hline Female & $\begin{array}{l}31 \text { EMS patients and } 27 \\
\text { controls }\end{array}$ & Serum & $\begin{array}{c}\text { Serum native thiols } \downarrow \\
\text { Total native thiols } \downarrow \\
\text { CAT } \uparrow\end{array}$ & [23] \\
\hline Female & $\begin{array}{l}30 \text { EMS patients and } 40 \\
\text { controls }\end{array}$ & Serum & $\begin{array}{c}\text { Iron } \uparrow \\
\text { MDA } \neq \\
\text { Carbonyl } \neq\end{array}$ & [26] \\
\hline & Murine model & & $\begin{array}{c}\text { Iron } \uparrow \\
\text { FSHR } \downarrow\end{array}$ & [32] \\
\hline
\end{tabular}

$\uparrow$ increased. $\downarrow$ decreased. $\neq$ no significant change.

\section{Apoptosis and EMS}

Apoptosis is a distinctive form of programmed cell death that provides efficient elimination of senescent cells and tissue homeostasis during the menstrual cycle without eliciting inflammatory reactions. While EMS's severity proved to be directly correlated with a fulminant production of ROS, this pathology also exerts antagonistic effects towards the functionality of apoptosis. Under normal circumstances, apoptosis usually prevents the migration and accumulation of ectopic and eutopic endometrial cells by destroying them before they have the opportunity to form necrotic tissue [34,35].

Several recent studies thoroughly described this correlation and explained the mechanisms in which endometrial cells apoptosis is modulated. On the one hand, it was shown 
that one of the most important apoptotic pathways in EMS endometrium is the Bcl-2 familymediated mechanism. Moreover, in an EMS animal model study, Mulyantoro et al. [36] reported the effects of Bcl-2/Bax modulation on the abdominal and pelvic peritoneal tissues EMS implants concluding that the fate of the endometrial implants in the peritoneal tissues could be directly correlated to the Bcl-2/Bax expression. Moreover, Delbandi et al. [37] showed that there could be several differences in this mechanism's modulation considering the origin of the EMS cells (ectopic versus eutopic). In this way, it seems that the anti-apoptotic signaling molecules (Bcl-2 and $\mathrm{Bcl}-\mathrm{xL}$ ) are expressed with a higher frequency in the ectopic EMS tissues suggesting that the apoptotic signals modulation could be implicated in the fate of the EMS cells. Furthermore, the study also reported the implication of lower caspase-3 pro-apoptotic activity (as an important component of Fas apoptotic pathway) in the eutopic EMS tissues implying that EMS development could be a matter of extrinsic and intrinsic apoptosis modulation. However, the authors suggested that the Fas apoptotic pathway could be implicated in the EMS preventive mechanism induced by immune activation, thus showing an important correlation between apoptosis modulation and inflammatory response.

In this context, Li et al. [38] showed that the upregulation of caspase-3 expression is concomitant with and correlated to the expression of the signal transducer and activator of transcription 1 (STAT1), which is also an important signal molecule in inflammatory response modulation. In addition, in a study of the potential beneficial effect of Kuntai Capsule (KTC) on apoptosis, Zhong et al. [39] showed that the modulation of caspase-8, caspase-9, caspase-3, and cytochrome could promote apoptosis in the EMS tissues. However, the authors pointed that the positive effect of Kuntai Capsule formulation could be effective only on the ectopic EMS tissues, clearly suggesting the differences between the mechanisms underlying ectopic and eutopic apoptosis. Moreover, a similar study pointed out that OS could also be implicated in this equation, since a correlation (yet not causation) could be established between the increased level of serum ROS and the decreased antioxidant enzymes activity (namely, SOD and CAT) and apoptosis rate, Bax, Bcl-2, and caspase-3 expression. Furthermore, the authors described the mechanism in which ROS could be implicated in the mitochondrial apoptotic JNK signaling pathway. We previously discussed the implication of this type of apoptosis in accordance with iron-mediated mitochondrial OS. Thus, it seems that there could be a close interaction between the OS mechanisms occurring as important effects of EMS tissues stimulation and development and the cell proliferation/apoptosis signaling. Caspase-3 was also previously described to be a key modulation point in the EMS apoptotic pathways [40].

On the other hand, Zhong et al. [39] also mentions the importance of traditional Chinese medicine known as the Kuntai Capsule on EMS pathogenesis by normalizing the expression of several pro-inflammatory and apoptotic mediators after three weeks of administration. Meldrum et al. [41] demonstrated that the growth of ectopic endometrium could be sensitive to hormone stimulation. It was previously shown that the impairments of estrogen-mediated cellular signaling could lead to important changes in TNF- $\alpha$ and IL-1 $\beta$ activities [42], thus suggesting that hormonal and inflammatory modulation could be correlated in EMS through the estrogen receptor (ER) $\beta$ implication. Additionally, the escape of immune surveillance caused by ER $\beta$ could further interact with the apoptotic machinery and cytoplasmic inflammasome in the cytoplasm. Further studies showed that estrogen could promote Bcl-2 regulation and thymic stromal lymphopoietin (TSLP) secretion [43] and influence the steroid receptor coactivator (SRC-1) [44] (progesterone pathway). The way in which the latter is implicated in EMS was also correlated to apoptosis mechanisms (TNF $\alpha$-mediated apoptosis) and inflammation (inflammatory signaling in endometriotic lesions), according to Han et al., 2012 [45] and Han et al., 2015 [42]. In this context, it was shown that p53 levels in ovarian endometriotic tissues are also correlated to the hormonal modulation (secretory phase versus proliferative phase) [46] and that depo-medroxyprogesterone acetate (DMPA), a progesterone derivate, could modulate cell proliferation and apoptosis in EMS women, but only in eutopic lesions cases [47]. 
However, Song et al. [48] recently showed that Bcl-2 modulation could also be implicated in cell proliferation and apoptosis in both eutopic and ectopic EMS tissues. In this way, the study that evaluated the EMS cell survival reported that the knockdown of YAP in ectopic endometrial stromal cells diminished cell proliferation but increased cell apoptosis concomitant with the decrease in expression of the transcriptional enhancer factor TEF-1 (TEAD1), connective tissue growth factor (CTGF), and Bcl-2. The overexpression of YAP also promoted an exaggerated proliferation and weakened apoptosis of normal endometrial stromal cells suggesting that the Hippo/Yes-associated protein (YAP) pathway is also an important component of apoptosis regulation in both ectopic and eutopic EMS lesion [48].

Other candidates for the potent apoptotic modulators in EMS were described by Bilgic et al. [49]. They showed that downregulation and/or alteration of endocannabinoid receptors could mediate the underlying mechanism of EMS and adenomyosis. Both CB1 and CB2 and also several key enzymes on the endocannabinoid pathway, such as fatty acid amide hydrolase (FAAH), N-acyl phosphatidylethanolamine phospholipase D (NAPE-PLD), diacylglycerol lipase (DAGL), and monoacylglycerol lipase (MAGL), were significantly impaired in endometriotic and adenomyotic tissues leading to a valid model of apoptotic signaling in EMS.

The much more complex TNF- $\alpha$-mediated apoptosis in EMS still remains to be fully elucidated, since Tian et al. and Long et al. [50,51] described the mechanism through which the activation of this process could also be mediated by death-associated protein kinase 1 (DAPK1), c-Jun, and miRNAs. Another yet fully undiscovered mechanism is the implication of $\mathrm{Ca}+$ and Cav1.3 channels in cell proliferation, aggregation, and apoptosis [52]. However, Yang et al. [52] already described the implication of the Cav1.3 channel, which is expressed in EMS tissue and primary ESCs cells and is highly sensitive to prostaglandin 2 and could modulate caspase 3-mediated apoptosis. The mitogen-activated protein kinase/ERK kinase (MEK)/extracellular signal-regulated kinase (ERK) signaling pathway has also been proposed to fulfil the important role(s) in cell proliferation, apoptosis, and migration. This is the reason why Chen et al. [53] studied these pathways in the EMS context and found that the modulation of these processes could lead to the proliferation, migration, and apoptosis control of the endometrial stromal cells in EMS.

Table 2. Summary content regarding the outcomes in which we investigated the apoptotic and potential markers.

\begin{tabular}{|c|c|c|c|}
\hline Subject & Number & Regulatory Pathway & Reference \\
\hline \multicolumn{4}{|c|}{ Experimental Models } \\
\hline $\mathrm{BALB} / \mathrm{c}$ mice & $n=33$ mice & $\begin{array}{c}\mathrm{Bcl}-2 \downarrow \\
\mathrm{Bax} \downarrow\end{array}$ & [36] \\
\hline BALB/c nude & $n=5$ per group & $\mathrm{Bcl}-2 \uparrow \downarrow$ & [48] \\
\hline C57BL/6J mice & $n=3$ per group & $\mathrm{ER} \beta \uparrow$ & [44] \\
\hline 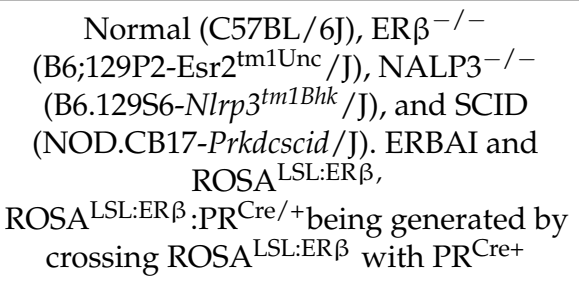 & $n=4$ & $E R \beta \uparrow \downarrow$ & [42] \\
\hline 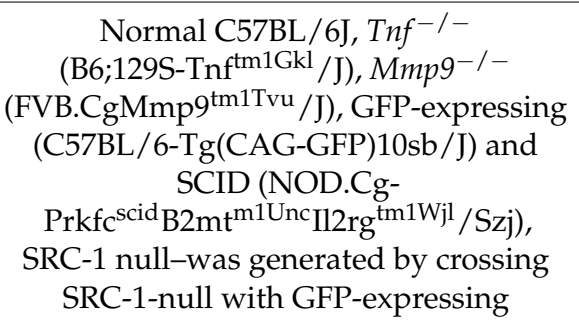 & $n=6$ & MMP9 $\uparrow$ & [45] \\
\hline
\end{tabular}


Table 2. Cont.

\begin{tabular}{|c|c|c|c|}
\hline Subject & Number & Regulatory Pathway & Reference \\
\hline Sprague- Dawley rats & $n=74$ & $\begin{array}{c}\text { caspase- } 3 \uparrow \\
\text { caspase- } 8 \uparrow \\
\text { caspase- } 9 \uparrow \\
\text { cytochrome } \uparrow\end{array}$ & [39] \\
\hline \multicolumn{4}{|c|}{ Culture(s)-In Vivo } \\
\hline Human endometrial stromal cells & $\begin{array}{c}n=32 ; n=16 \text { peritoneal or OE or } \\
\text { both and } n=16 \text { controls; } n=12 \\
\text { dermoid cysts and } n=3 \text { serous } \\
\text { cystadenoma and } n=1 \text { simple } \\
\text { ovarian cyst }\end{array}$ & $\begin{array}{l}\text { caspase-3 } \uparrow \\
\operatorname{miR}-21-5 \mathrm{p} \uparrow\end{array}$ & [40] \\
\hline Human endometrial stromal cells & $n=25 \mathrm{OE}$ and $n=5$ pelvic EMS & $\mathrm{Bcl}-2 \uparrow \downarrow$ & [43] \\
\hline \multicolumn{2}{|c|}{ Human ectopic and normal endometrial cells } & $\begin{array}{c}\text { STAT1 } \uparrow \\
\text { caspase- } 3 \uparrow\end{array}$ & [38] \\
\hline $\begin{array}{l}\text { Human eutopic and ectopic ESCs } \\
\text { controls }\end{array}$ & $n=17, n=11$, and $n=15$ & $\begin{array}{c}\text { Bcl- } 2 \uparrow \\
\text { Bcl-xL } \uparrow \\
\text { caspase-3 } \downarrow \\
\text { VEGF-A } \uparrow \\
\text { HGF } \uparrow\end{array}$ & [37] \\
\hline
\end{tabular}

\section{Cell line(s)-In Vitro}

$n=20$ EMS patients, $n=17$ adenomyosis and $n=19$ controls;

$n=12$ proliferative, $n=7 \quad$ CB1 $\downarrow$
secretory; Endometriosis tissues $\quad \mathrm{CB} 2 \downarrow$

Female/CRL-7566 cell line were divided as: $n=9$ cystic and

$$
n=11 \text { non-cystic }
$$

\begin{tabular}{|c|c|c|c|}
\hline $\begin{array}{l}\text { Female/HEK293T, CRL7566, CRL-11731 } \\
\text { cell lines }\end{array}$ & $\begin{array}{c}n=10 \mathrm{OE}, n=10 \text { ovarian cancer, } \\
\text { and } n=10 \text { controls }\end{array}$ & miR-191 $\downarrow$ & [50] \\
\hline Female/CRL-7566 cell line & $\begin{array}{c}n=20 \text { eutopic and ectopic } \\
\text { endometrium }\end{array}$ & $\begin{array}{c}\operatorname{miR}-29 \mathrm{c} \uparrow \downarrow \\
\mathrm{c}-J u n \uparrow \downarrow\end{array}$ & [51] \\
\hline Female/hEM15A cell line & $n=30 \mathrm{OE}$ and $n=30$ controls & 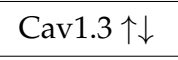 & {$[52]$} \\
\hline \multicolumn{4}{|c|}{ Human patients } \\
\hline Female & $\begin{array}{l}n=30 \mathrm{OE} \text { and } n=29 \\
\text { controls }\end{array}$ & 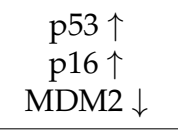 & [46] \\
\hline Female & $\begin{array}{c}n=28 \text { EMS patients, } n=14 \\
\text { laparoscopy after DMPA injection } \\
\text { and } n=14 \\
\text { laparoscopy without DMPA } \\
\text { injection }\end{array}$ & $\mathrm{PCNA} \neq$ & [47] \\
\hline Female & $\begin{array}{c}n=30 \text { EMS patients and } n=15 \\
\text { controls }\end{array}$ & Raf-1 $\uparrow$ & {$[53]$} \\
\hline
\end{tabular}

$\uparrow$ increased. $\downarrow$ decreased. $\uparrow \downarrow$ regulatory. $\neq=$ no significant change.

\section{Endobiota and EMS}

Regarding the microbiota interaction with the reproductive system functions, it was previously shown that the vaginal, cervical, and gut microbiota could be implicated in the pathogenesis of EMS. In this way, Ata et al. [54], in a study on the endobiota status in EMS-diagnosed women, showed the total absence of Atopobium in both vaginal and cervical microbiota of EMS group, and also the presence of Gardnerella, Streptococcus, Escherichia, Shigella, and Ureaplasma in the cervical samples. Moreover, Cregger et al. [55] suggested that the richness and phylogenetic diversity were increased in stage III EMS, as compared 
to healthy individuals, and that the surgical intervention for EMS tissues neutralization reversed the endobiota characteristics for a limited period of time. In this context, while the bacterial contamination EMS development hypothesis suggests that EMS pathogenesis and inflammation are correlated by the microbial pathogens reaching the endometrial space [56], it was shown that in an EMS mice model, the reduction of the ectopic lesions and the magnitude of the inflammatory response could both be modulated at the same time through antibiotic administration [57]. Furthermore, it is important to mention that both OS-related apoptotic signals and the inflammatory response are modulated differently, considering the origin of the elicitors. In this way, Chen et al. [58] suggested that, during vaginal inflammation due to pathogens invasion, the immune response could also be triggered by ROS overproduction, eventually leading to an apoptotic signal via neutrophilic activation (caspase-3 mediated). A similar mechanism was previously described for apoptotic modulation in the ectopic endothelial stromal cells underlying EMS tumors.

However, despite that the most prevalent microbiota component was the Lactobacillus genus members, Wei et al. [59] showed that as advancing up the reproductive tract, the microflora diversity increases, as they observed by sampling the vagina, posterior vaginal fornix, cervical mucus, endometrium, and peritoneal fluid. Moreover, Riganelli et al. [60] suggested that reproductive system-colonizing Lactobacillus species could play an important role in more than mucosa maintenance, as they observed that the differences between in vitro fertilized pregnant and non-pregnant women mainly reside in the vaginal and endometrial microbiota diversity. Moreover, it is known that lactobacilli are a continuous source of $\mathrm{H}_{2} \mathrm{O}_{2}$, which could contribute to intrinsic protective mechanisms, thus the possible implication of this microbiota component in OS and apoptosis modulation [59].

Furthermore, it could be suggested that there could be an interaction between the hormonal fluctuations during the menstrual cycle and reproductive system microbiota. However, disregarding that microbial taxa and potential functions proved to be positively correlated with the menstrual cycle or are over-represented in patients with adenomyosis and/or infertility caused by EMS [61], Akiyama et al. [62] showed that the distribution of microbiota in the cervical mucus of women with and without EMS is very similar and that regardless of the menstrual cycle phase, Lactobacillus spp. were dominant, concomitantly with an increased ratio of Corynebacterium, Enterobacteriaceae, Flavobacterium, Pseudomonas, and Streptococcus in the EMS group. Enterobacteriaceae and Streptococcus were considered to be significant candidates in the EMS group compared to in controls. Furthermore, considering the previously mentioned implications of estrogen in apoptosis, Leonardi et al. [56] thoroughly discussed the role of microbiota in estrogen metabolism in EMS with regards to the changes occurring in the gut microbiota. In this way, it was suggested that EMS development and progression could be very much influenced by the prevalence of the bacteria that produce enzymes for estrogen deconjugation in the gut.

Considering these aspects, further investigations were carried out on animal models in order to elucidate the way in which gut, vaginal, and endometrial microbiota are implicated in the EMS occurrence and development. In this way, using transgenic green fluorescent protein $(\mathrm{GFP})^{+}$donor mice and the standard antitumor and immunologic studies mice strain C57BL/6, Hantschel et al. [63] demonstrated that the uterine tissues fragment transplantation receiver mice exhibited significant differences in terms of gut microbiota, alongside the typical tissue morphology of the lesions and ease of differentiating GFP-host tissues. In a similar study, Yuan et al. [64] also described the gut microbiota alterations during EMS development via intraperitoneal injection of endometrial tissues in C57BL/6 mice, as both EMS and mock groups shared an identical microenvironment and richness until day 42. There was a significantly different ratio among Firmicutes/Bacteroidetes in the EMS group, and Bifidobacterium was also increased in this group, suggesting that lesion development and dysbacteriosis could be correlated. Considering this, Hu et al. [65] further analyzed the existence of an inflammatory response of the uterus in FMT-mice and observed that EMS induced by pathogenic bacteria inoculation could be more severe, but reversible. Moreover, considering the molecular changes that can be observed in this context, 
the authors noted a significant decrease in the short-chain fatty acids (SCFAs) in the feces of mice with dysbiosis and the administered treatment with sodium butyrate/propionate increased the overall concentration in both circulation and uterine tissues. Furthermore, the study reported the increase in pathogen load in the uteri of dysbiosis-associated mice, which could explain the restricted phagocytic ability and responsiveness of neutrophils.

A crucial yet underestimated microbial composition modulator could also be the pathogens encountered in the reproductive system. In this way, several studies reported high human papillomavirus prevalence [66-68] in association with EMS. In all these cases, the main aim was to investigate whether sexually transmitted viruses (STDs) or prokaryotes such as human HPVs, herpes viruses, and Chlamydia trachomatis in the lower and upper female genital tract are correlated with EMS injuries. Considering that herpes viruses and Chlamydia trachomatis were not detected in endometriosis lesions, HPV was prevalent in all samples analyzed in both categories: With and without EMS. The risk is higher, even double, in patients with EMS, with all positive patients having been previously detected with an HPV infection. As expected, the risk towards medium (md) and high (hr) HPV was in females with EMS in both lower and upper genital tract. However, Vestergaard et al. [69] contradicts these findings and sustain that no significant differences were observed in terms of virus prevalence in endometriotic lesions.

Table 3. Summary content regarding the outcomes in which we investigated the microbial taxa in EMS.

\begin{tabular}{|c|c|c|c|c|}
\hline Subject & Number & Region Analyzed & Microbial Taxa Differences & Reference \\
\hline Female & $\begin{array}{c}14 \text { stage } 3 / 4 \frac{3}{4} \text { EMS women and } 14 \\
\text { controls }\end{array}$ & V3-V4 region $16 \mathrm{~S}$ rRNA & $\begin{array}{c}\text { Atopobium absence in the vaginal } \\
\text { and cervical microbiota } \\
\uparrow \text { Gardnerella } \\
\uparrow \text { Streptococcus } \\
\uparrow \text { Escherichia } \\
\uparrow \text { Shigella } \\
\uparrow \text { Ureoplasma } \\
\text { Prevalence of Shigella and Escherichia } \\
\text { in the stool }\end{array}$ & [54] \\
\hline Female & $\begin{array}{l}19 \text { women; } n=10 \text { distinct EMS } \\
\text { stages and } n=9 \text { controls }\end{array}$ & V3-V5 region 16S rRNA & $\begin{array}{c}\text { Significant alterations among } \\
\text { bacterial communities depending on } \\
\text { the site from which the sample was } \\
\text { collected and diagnosis }\end{array}$ & [55] \\
\hline Female & 36 EMS women and 14 controls & V4-V5 region 16S rRNA & $\begin{array}{l}\text { Prevalence of Lactobacillus in the } \\
\text { lower third of the vagina and } \\
\text { posterior vaginal fornix. } \\
\text { Differences among communities } \\
\text { were visible starting from the } \\
\text { cervical mucus of EMS patients, } \\
\text { gradually increasing towards the } \\
\text { reproductive system. } \\
\uparrow \text { Operational Taxonomic Units in } \\
\text { the cervical mucus, endometrium, } \\
\text { and peritoneal fluid. }\end{array}$ & [59] \\
\hline Female & 34 women & V4-V4 region $16 \mathrm{~S}$ rRNA & $\begin{array}{c}\text { Lactobacilli-dominant } \\
\text { microenvironment in contrast to } \\
\text { non-pregnant women, whereas the } \\
\text { endometrial bacterial colonization } \\
\text { was marker exclusively by a } \\
\text { polymicrobial habitat in which } \\
\text { lactobacilli were predominant }\end{array}$ & {$[60]$} \\
\hline
\end{tabular}


Table 3. Cont.

\begin{tabular}{|c|c|c|c|c|}
\hline Subject & Number & Region Analyzed & Microbial Taxa Differences & Reference \\
\hline Female & 39 EMS women and 30 controls & V5-V6 region 16S rRNA & $\begin{array}{c}\text { Similar microbial taxa between } \\
\text { women with and without EMS. } \\
\uparrow \text { Lactobacilli spp } \\
\uparrow \text { Corynebacterium } \\
\uparrow \text { Enterobacteriaceae in EMS group } \\
\text { than in control }(p<0.05) \\
\uparrow \text { Flavobacterium } \\
\uparrow \text { Pseudomonas } \\
\uparrow \text { Streptococcus in EMS group than } \\
\text { in Control }(p<0.05)\end{array}$ & {$[62]$} \\
\hline Mice & $\begin{array}{l}\text { C57BL/6 wild-type mice and } \\
\text { transgenic C57BL/6-TgN(ACTB- } \\
\text { EGFP)1Osb/J donor mice; } 4 \text { per } \\
\text { cage-2 EMS and } 2 \\
\text { sham-transplanted controls }\end{array}$ & V4-V5 region16S rRNA & $\begin{array}{l}\text { No significant difference between } \\
\text { groups, being speculated that EMS } \\
\text { does not induce a dysbiosis during } \\
\text { the acute phase of lesion formation. }\end{array}$ & [63] \\
\hline Mice & $\begin{array}{l}\text { C57BL6; } 22 \text { from which in } 4 \\
\text { distinct intervals (day } 7,14 \text {, and } \\
\text { 28) fecal sample was collected and } \\
\text { the mice were sacrificed for model } \\
\text { confirmation; } 8 \text { out of } 10 \text { in day } 42 \text {. }\end{array}$ & V4 region $16 \mathrm{~S}$ rRNA & $\begin{array}{c}\text { Similar diversity and richness } \\
\text { between EMS and mock mice. } \\
\uparrow \text { Firmicutes/Bacteroidetes ratio in } \\
\text { EMS after } 42 \text { days } \\
\uparrow \text { Bifidobacterium in EMS group }\end{array}$ & {$[64]$} \\
\hline Mice & BALB/c mice & V4 region 16S rRNA & $\begin{array}{l}\uparrow \text { pathogen load in the uteri of gut } \\
\text { microbiota-dysbiosis mice }\end{array}$ & {$[65]$} \\
\hline
\end{tabular}

$\uparrow$ increased.

\section{Conclusions}

Based on all aspects discussed throughout this manuscript, we could suggest that endometriosis exerts a pronounced detrimental effect on an organism's integrity. Overall, clear changes of oxidative biomarkers levels could be observed, the associated repercussions being branched and reflected by an abnormal expression of apoptosis-related mediators that ultimately lead to a dysbiosis. The current knowledge in endometriosis pathophysiology offers some explanation for the crucial roles that oxidative stress, apoptosis, and endobiota possess in various gynecological disorders, further outlining the multifactorial character of endometriosis.

Author Contributions: O.-D.I.; I.-M.B.; R.M.; I.S. (Ioana Scripcariu); G.S.; D.G.; I.S. (Irina Stoian) (conceptualization, data curation, investigation, formal analysis, methodology, writing-original draft); B.D.; A.C.; C.I. (conceptualization, methodology, writing-review and editing); B.D.; A.C.; C.I. (supervision, validation, project administration). All authors have read and agreed to the published version of the manuscript.

Funding: This research received no external funding.

Data Availability Statement: The datasets used and analyzed during the current study are available from the corresponding author on reasonable request.

Acknowledgments: Not applicable.

Conflicts of Interest: The authors declare no conflict of interest.

\section{References}

1. Bazot, M.; Bharwani, N.; Huchon, C.; Kinkel, K.; Cunha, T.M.; Guerra, A.; Manganaro, L.; Buñesch, L.; Kido, A.; Togashi, K.; et al. European Society of Urogenital Radiology (ESUR) Guidelines: MR Imaging of Pelvic Endometriosis. Eur. Radiol. 2017, 27, 2765-2775. [CrossRef] [PubMed]

2. Vercellini, P.; Viganò, P.; Somigliana, E.; Fedele, L. Endometriosis: Pathogenesis and Treatment. Nat. Rev. Endocrinol. 2014, 10, 261-275. [CrossRef] 
3. Zondervan, K.T.; Becker, C.M.; Koga, K.; Missmer, S.A.; Taylor, R.N.; Viganò, P. Endometriosis. Nat. Rev. Dis. Prim. 2018 , 4, 9. [CrossRef]

4. Johnson, N.P.; Hummelshoj, L.; Adamson, G.D.; Keckstein, J.; Taylor, H.S.; Abrao, M.S.; Bush, D.; Kiesel, L.; Tamimi, R.; SharpeTimms, K.L.; et al. World Endometriosis Society Consensus on the Classification of Endometriosis. Hum. Reprod. 2017, 32, 315-324. [CrossRef]

5. Czyzyk, A.; Podfigurna, A.; Szeliga, A.; Meczekalski, B. Update on Endometriosis Pathogenesis. Minerva Ginecol. 2017, 69, 447-461.

6. Sampson, J.A. Peritoneal Endometriosis Due to the Menstrual Dissemination of Endometrial Tissue into the Peritoneal Cavity. Am. J. Obstet. Gynecol. 1927, 14, 422-469. [CrossRef]

7. Halme, J.; Hammond, M.G.; Hulka, J.F.; Raj, S.G.; Talbert, L.M. Retrograde Menstruation in Healthy Women and in Patients with Endometriosis. Obstet. Gynecol. 1984, 64, 151-154. [PubMed]

8. Liu, D.T.; Hitchcock, A. Endometriosis: Its Association with Retrograde Menstruation, Dysmenorrhoea and Tubal Pathology. Br. J. Obstet. Gynaecol. 1986, 93, 859-862. [CrossRef]

9. Sourial, S.; Tempest, N.; Hapangama, D.K. Theories on the Pathogenesis of Endometriosis. Int. J. Reprod. Med. 2014, 2014, 179515. [CrossRef]

10. Ahn, S.H.; Monsanto, S.P.; Miller, C.; Singh, S.S.; Thomas, R.; Tayade, C. Pathophysiology and Immune Dysfunction in Endometriosis. Biomed. Res. Int. 2015, 2015, 795976. [CrossRef]

11. Gordts, S.; Koninckx, P.; Brosens, I. Pathogenesis of Deep Endometriosis. Fertil. Steril. 2017, 108, 872-885. [CrossRef] [PubMed]

12. Halme, J.; Becker, S.; Hammond, M.G.; Raj, M.H.G.; Raj, S. Increased Activation of Pelvic Macrophages in Infertile Women with Mild Endometriosis. Am. J. Obstet. Gynecol. 1983, 145, 333-337. [CrossRef]

13. Keettel, W.C.; Stein, R.J. The Viability of the Cast-Off Menstrual Endometrium. Am. J. Obstet. Gynecol. 1951, 61, 440-442. [CrossRef]

14. Nisolle, M.; Paindaveine, B.; Bourdon, A.; Berlière, M.; Casanas-Roux, F.; Donnez, J. Histologic Study of Peritoneal Endometriosis in Infertile Women. Fertil. Steril. 1990, 53, 984-988. [CrossRef]

15. Kruitwagen, R.F.P.M.; Poels, L.G.; Willemsen, W.N.P.; de Ronde, I.J.Y.; Jap, P.H.K.; Rolland, R. Endometrial Epithelial Cells in Peritoneal Fluid during the Early Follicular Phase. Fertil. Steril. 1991, 55, 297-303. [CrossRef]

16. Arumugam, K.; Lim, J.M. Menstrual Characteristics Associated with Endometriosis. Br. J. Obstet. Gynaecol. 1997, 104, 948-950. [CrossRef] [PubMed]

17. Vercellini, P.; De Giorgi, O.; Aimi, G.; Panazza, S.; Uglietti, A.; Crosignani, P.G. Menstrual Characteristics in Women with and Without Endometriosis. Obstet. Gynecol. 1997, 90, 264-268. [CrossRef]

18. Kvaskoff, M.; Mu, F.; Terry, K.L.; Harris, H.R.; Poole, E.M.; Farland, L.; Missmer, S.A. Endometriosis: A High-Risk Population for Major Chronic Diseases? Hum. Reprod. Update 2015, 21, 500-516. [CrossRef] [PubMed]

19. Bulun, S.E.; Yilmaz, B.D.; Sison, C.; Miyazaki, K.; Bernardi, L.; Liu, S.; Kohlmeier, A.; Yin, P.; Milad, M.; Wei, J. Endometriosis. Endocr. Rev. 2019, 40, 1048-1079. [CrossRef]

20. Young, V.B. The Role of the Microbiome in Human Health and Disease: An Introduction for Clinicians. BMJ 2017, 356. [CrossRef]

21. Khan, K.N.; Fujishita, A.; Hiraki, K.; Kitajima, M.; Nakashima, M.; Fushiki, S.; Kitawaki, J. Bacterial Contamination Hypothesis: A New Concept in Endometriosis. Reprod. Med. Biol. 2018, 17, 125-133. [CrossRef]

22. Amreen, S.; Kumar, P.; Gupta, P.; Rao, P. Evaluation of Oxidative Stress and Severity of Endometriosis. J. Hum. Reprod. Sci. 2019, $12,40-46$.

23. Turkyilmaz, E.; Yildirim, M.; Cendek, B.D.; Baran, P.; Alisik, M.; Dalgaci, F.; Yavuz, A.F. Evaluation of Oxidative Stress Markers and Intra-Extracellular Antioxidant Activities in Patients with Endometriosis. Eur. J. Obstet. Gynecol. Reprod. Biol. 2016, 199, 164-168. [CrossRef]

24. Elsharkawy, S.S.; Abdrabo, S.M.; Khalil, H.M.; Mannaa, F.H. Evaluation of Oxidative Stress Markers in Serum and Follicular Fluid of Women with Infertility Related to Endometriosis. J. Clin. Obstet. Gynecol. Infertility 2020, 4, 1045.

25. Juan, C.A.; Pérez de la Lastra, J.M.; Plou, F.J.; Pérez-Lebeña, E. The Chemistry of Reactive Oxygen Species (ROS) Revisited: Outlining Their Role in Biological Macromolecules (DNA, Lipids and Proteins) and Induced Pathologies. Int. J. Mol. Sci. 2021, 22, 4642. [CrossRef] [PubMed]

26. Alizadeh, M.; Mahjoub, S.; Esmaelzadeh, S.; Hajian, K.; Basirat, Z.; Ghasemi, M. Evaluation of Oxidative Stress in Endometriosis: A Case-Control Study. Casp. J. Intern. Med. 2015, 6, 25-29.

27. Nasiri, N.; Moini, A.; Eftekhari-Yazdi, P.; Karimian, L.; Salman Yazdi, R.; Arabipoor, A. Oxidative Stress Statues in Serum and Follicular Fluid of Women with Endometriosis. Cell J. 2017, 18, 582-587. [PubMed]

28. Montoya-Estrada, A.; Coria-García, C.F.; Cruz-Orozco, O.P.; Aguayo-González, P.; Torres-Ramos, Y.D.; Flores-Herrera, H.; Hicks, J.J.; Medina-Navarro, R.; Guzmán-Grenfell, A.M. Increased Systemic and Peritoneal Oxidative Stress Biomarkers in Endometriosis Are Not Related to Retrograde Menstruation. Redox Rep. 2019, 24, 51-55. [CrossRef]

29. Thézénas, M.-L.; De Leo, B.; Laux-Biehlmann, A.; Bafligil, C.; Elger, B.; Tapmeier, T.; Morten, K.; Rahmioglu, N.; Dakin, S.G.; Charles, P.; et al. Amine Oxidase 3 Is a Novel Pro-Inflammatory Marker of Oxidative Stress in Peritoneal Endometriosis Lesions. Sci. Rep. 2020, 10, 1495. [CrossRef] 
30. Polak, G.; Barczyński, B.; Wertel, I.; Kwaśniewski, W.; Bednarek, W.; Derewianka-Polak, M.; Frąszczak, K.; Olajossy, M.; Kotarski, J. Disrupted Iron Metabolism in Peritoneal Fluid May Induce Oxidative Stress in the Peritoneal Cavity of Women with Endometriosis. Ann. Agric. Environ. Med. 2018, 25, 587-592. [CrossRef]

31. Chen, C.; Zhou, Y.; Hu, C.; Wang, Y.; Yan, Z.; Li, Z.; Wu, R. Mitochondria and Oxidative Stress in Ovarian Endometriosis. Free Radic. Biol. Med. 2019, 136, 22-34. [CrossRef]

32. Hayashi, S.; Nakamura, T.; Motooka, Y.; Ito, F.; Jiang, L.; Akatsuka, S.; Iwase, A.; Kajiyama, H.; Kikkawa, F.; Toyokuni, S. Novel Ovarian Endometriosis Model Causes Infertility via Iron-Mediated Oxidative Stress in Mice. Redox Biol. 2020, $37,101726$. [CrossRef]

33. González-Foruria, I.; Santulli, P.; Chouzenoux, S.; Carmona, F.; Chapron, C.; Batteux, F. Dysregulation of the ADAM17/Notch Signalling Pathways in Endometriosis: From Oxidative Stress to Fibrosis. Mol. Hum. Reprod. 2017, 23, 488-499. [CrossRef]

34. Agic, A.; Djalali, S.; Diedrich, K.; Hornung, D. Apoptosis in Endometriosis. Gynecol. Obstet. Investig. 2009, 68, 217-223. [CrossRef]

35. Taniguchi, F.; Kaponis, A.; Izawa, M.; Kiyama, T.; Deura, I.; Ito, M.; Iwabe, T.; Adonakis, G.; Terakawa, N.; Harada, T. Apoptosis and Endometriosis. Front. Biosci. (Elite Ed.) 2011, 3, 648-662. [CrossRef] [PubMed]

36. Mulyantoro, I.; Indrapraja, O.; Widjiati, W.; Noerpramana, N.P. Effect of Metformin on Bcl-2/Bax Expression Ratio and Endometrial Implants: A Mouse Model in Endometriosis Study. J. Biomed. Transl. Res. 2020, 6, 53-58. [CrossRef]

37. Delbandi, A.-A.; Mahmoudi, M.; Shervin, A.; Heidari, S.; Kolahdouz-Mohammadi, R.; Zarnani, A.-H. Evaluation of Apoptosis and Angiogenesis in Ectopic and Eutopic Stromal Cells of Patients With Endometriosis Compared to Non-Endometriotic Controls. BMC Womens. Health 2020, 20, 3. [CrossRef] [PubMed]

38. Li, J.; Abudula, M.; Fan, X.; Wang, F.; Chen, Y.; Liu, L. Sunitinib Induces Primary Ectopic Endometrial Cell Apoptosis Through Up-Regulation of STAT1 In Vitro. J. Clin. Lab. Anal. 2020, 34, e23482. [CrossRef] [PubMed]

39. Zhong, R.; Ma, A.; Zhu, J.; Li, G.; Xie, S.; Li, Z.; Gui, Y.; Zhu, Y. Kuntai Capsule Inhibited Endometriosis via Inducing Apoptosis in a Rat Model. Evid. Based Complement. Altern. Med. 2016, 2016, 5649169. [CrossRef] [PubMed]

40. Park, J.; Lee, S.; Kim, M.-K.; Lee, J.; Yun, B.; Park, J.; Seo, S.K.; Cho, S.; Choi, Y. Saponin Extracts Induced Apoptosis of Endometrial Cells from Women with Endometriosis Through Modulation of miR-21-5p. Reprod. Sci. 2017, 25, 193371911771126. [CrossRef]

41. Meldrum, D.R.; Chang, R.J.; Lu, J.; Vale, W.; Rivier, J.; Judd, H.L. "Medical Oophorectomy" Using a Long-Acting gGnRHrh Agonist-A Possible New Approach to the Treatment of Endometriosis. J. Clin. Endocrinol. Metab. 1982, 54, 1081-1083. [CrossRef] [PubMed]

42. Han, S.J.; Jung, S.Y.; Wu, S.-P.; Hawkins, S.M.; Park, M.J.; Kyo, S.; Qin, J.; Lydon, J.P.; Tsai, S.Y.; Tsai, M.-J.; et al. Estrogen Receptor $\beta$ Modulates Apoptosis Complexes and the Inflammasome to Drive the Pathogenesis of Endometriosis. Cell 2015, 163, 960-974. [CrossRef]

43. Yang, H.; Kai, C.; Mei, J.; Zhou, W.-J.; Liu, L.; Yao, L.; Meng, Y.; Wang, M.; Ha, S.; Lai, Z.; et al. Estrogen Restricts the Apoptosis of Endometrial Stromal Cells by Promoting TSLP Secretion. Mol. Med. Rep. 2018, 18, 4410-4416. [CrossRef] [PubMed]

44. Cho, Y.J.; Lee, J.E.; Park, M.J.; O’Malley, B.W.; Han, S.J. Bufalin Suppresses Endometriosis Progression by Inducing Pyroptosis and Apoptosis. J. Endocrinol. 2018, 237, 255-269. [CrossRef]

45. Han, S.J.; Hawkins, S.M.; Begum, K.; Jung, S.Y.; Kovanci, E.; Qin, J.; Lydon, J.P.; DeMayo, F.J.; O’Malley, B.W. A New Isoform of Steroid Receptor Coactivator-1 Is Crucial for Pathogenic Progression of Endometriosis. Nat. Med. 2012, 18, 1102-1111. [CrossRef]

46. Sang, L.; Fang, Q.-J.; Zhao, X.-B. A Research on the Protein Expression of p53, p16, and MDM2 in Endometriosis. Medicine 2019, 98, e14776. [CrossRef] [PubMed]

47. Tingthanatikul, Y.; Tawarasumida, Y.; Lertvikool, S.; Wongkularb, A.; Sophonsritsuk, A.; Weerakiet, S.; Sroyraya, M.; Chansela, P.; Changklungmoa, N.; Songkoomkrong, S.; et al. DMPA Suppresses Cell Proliferation and Enhances Cell Apoptosis of Eutopic Endometrium in Women with Endometriosis: A Randomized Controlled Study. J. Med. Assoc. Thai. 2016, 99, 751-756.

48. Song, Y.; Fu, J.; Zhou, M.; Xiao, L.; Feng, X.; Chen, H.; Huang, W. Activated Hippo/Yes-Associated Protein Pathway Promotes Cell Proliferation and Anti-Apoptosis in Endometrial Stromal Cells of Endometriosis. J. Clin. Endocrinol. Metab. 2016, 101, 1552-1561. [CrossRef] [PubMed]

49. Bilgic, E.; Meydanli, E.; Köse, S.; Aydin, M.; Karaismailoğlu, E.; Akar, I.; Usubutun, A.; Korkusuz, P. Endocannabinoids Modulate Apoptosis in Endometriosis and Adenomyosis. Acta Histochem. 2017, 119, 523-532. [CrossRef] [PubMed]

50. Tian, X.; Xu, L.; Wang, P. MiR-191 Inhibits TNF- $\alpha$ Induced Apoptosis of Ovarian Endometriosis and Endometrioid Carcinoma Cells by Targeting DAPK1. Int. J. Clin. Exp. Pathol. 2015, 8, 4933-4942.

51. Long, M.; Wan, X.; La, X.; Gong, X.; Cai, X. MiR-29c Is Downregulated in the Ectopic Endometrium and Exerts Its Effects on Endometrial Cell Proliferation, Apoptosis and Invasion by Targeting C-Jun. Int. J. Mol. Med. 2015, 35, 1119-1125. [CrossRef] [PubMed]

52. Yang, Y.; Yuan, Y.; Ma, X.; Xing, F. Ca2+ Channel Subunit a 1D Inhibits Endometriosis Cell Apoptosis and Mediated by Prostaglandin E2. Ginekol. Pol. 2019, 90, 669-674. [CrossRef]

53. Chen, Q.; Hang, Y.; Zhang, T.; Tan, L.; Li, S.; Jin, Y. USP10 Promotes Proliferation and Migration and Inhibits Apoptosis of Endometrial Stromal Cells in Endometriosis through AC-Tivating the Raf-1/MEK/ERK Pathway. Am. J. Physiol. Physiol. 2018, 315, C863-C872. [CrossRef] [PubMed]

54. Ata, B.; Yildiz, S.; Turkgeldi, E.; Brocal, V.P.; Dinleyici, E.C.; Moya, A.; Urman, B. The Endobiota Study: Comparison of Vaginal, Cervical and Gut Microbiota Between Women with Stage 3/4 Endometriosis and Healthy Controls. Sci. Rep. 2019, 9, 2204. [CrossRef] 
55. Cregger, M.; Lenz, K.; Leary, E.; Leach, R.; Fazleabas, A.; White, B.; Braundmeier, A. Reproductive Microbiomes: Using the Microbiome as a Novel Diagnostic Tool for Endometriosis. Reprod. Immunol. Open Access 2017, 2. [CrossRef]

56. Leonardi, M.; Hicks, C.; El-Assaad, F.; El-Omar, E.; Condous, G. Endometriosis and the Microbiome: A Systematic Review. BJOG An. Int. J. Obstet. Gynaecol. 2020, 127, 239-249. [CrossRef]

57. Chadchan, S.B.; Cheng, M.; Parnell, L.A.; Yin, Y.; Schriefer, A.; Mysorekar, I.U.; Kommagani, R. Antibiotic Therapy with Metronidazole Reduces Endometriosis Disease Progression in Mice: A Potential Role for Gut Microbiota. Hum. Reprod. 2019, 34, 1106-1116. [CrossRef] [PubMed]

58. Chen, Z.; Zhang, Z.; Zhang, H.; Xie, B. Analysis of the Oxidative Stress Status in Nonspecific Vaginitis and Its Role in Vaginal Epithelial Cells Apoptosis. Biomed. Res. Int. 2015, 2015, 795656. [CrossRef]

59. Wei, W.; Zhang, X.; Tang, H.; Zeng, L.; Wu, R. Microbiota Composition and Distribution Along the Female Reproductive Tract of Women with Endometriosis. Ann. Clin. Microbiol. Antimicrob. 2020, 19, 1-8. [CrossRef] [PubMed]

60. Riganelli, L.; Iebba, V.; Piccioni, M.; Illuminati, I.; Bonfiglio, G.; Neroni, B.; Calvo, L.; Gagliardi, A.; Levrero, M.; Merlino, L.; et al. Structural Variations of Vaginal and Endometrial Microbiota: Hints on Female Infertility. Front. Cell. Infect. Microbiol. 2020, 10, 350. [CrossRef] [PubMed]

61. Agostinis, C.; Mangogna, A.; Bossi, F.; Ricci, G.; Kishore, U.; Bulla, R. Uterine Immunity and Microbiota: A Shifting Paradigm. Front. Immunol. 2019, 10, 2387. [CrossRef]

62. Akiyama, K.; Nishioka, K.; Khan, K.N.; Tanaka, Y.; Mori, T.; Nakaya, T.; Kitawaki, J. Molecular Detection of Microbial Colonization in Cervical Mucus of Women with and without Endometriosis. Am. J. Reprod. Immunol. 2019, 82, e13147. [CrossRef]

63. Hantschel, J.; Weis, S.; Schäfer, K.-H.; Menger, M.D.; Kohl, M.; Egert, M.; Laschke, M.W. Effect of Endometriosis on the Fecal Bacteriota Composition of Mice during the Acute Phase of Lesion Formation. PLoS ONE 2019, 14, e0226835. [CrossRef]

64. Yuan, M.; Li, D.; Zhang, Z.; Sun, H.; An, M.; Wang, G. Endometriosis Induces Gut Microbiota Alterations in Mice. Hum. Reprod. 2018, 33, 607-616. [CrossRef] [PubMed]

65. Hu, X.; Mu, R.; Xu, M.; Yuan, X.; Jiang, P.; Guo, J.; Cao, Y.; Zhang, N.; Fu, Y. Gut Microbiota Mediate the Protective Effects on Endometritis Induced by Staphylococcus aureus in Mice. Food Funct. 2020, 11, 3695-3705. [CrossRef]

66. Oppelt, P.; Renner, S.P.; Strick, R.; Valletta, D.; Mehlhorn, G.; Fasching, P.A.; Beckmann, M.W.; Strissel, P.L. Correlation of High-Risk Human Papilloma Viruses but Not of Herpes Viruses or Chlamydia trachomatis with Endometriosis Lesions. Fertil. Steril. 2010, 93, 1778-1786. [CrossRef] [PubMed]

67. Heidarpour, M.; Derakhshan, M.; Derakhshan-Horeh, M.; Kheirollahi, M.; Dashti, S. Prevalence of High-Risk Human Papillomavirus Infection in Women with Ovarian Endometriosis. J. Obstet. Gynaecol. Res. 2017, 43, 135-139. [CrossRef]

68. Rocha, R.M.; Souza, R.P.; Gimenes, F.; Consolaro, M.E.L. The High-Risk Human Papillomavirus Continuum Along the Female Reproductive Tract and Its Relationship to Infertility and Endometriosis. Reprod. Biomed. Online 2019, 38, 926-937. [CrossRef]

69. Vestergaard, A.L.; Knudsen, U.B.; Munk, T.; Rosbach, H.; Bialasiewicz, S.; Sloots, T.P.; Martensen, P.M.; Antonsson, A. Low Prevalence of DNA Viruses in the Human Endometrium and Endometriosis. Arch. Virol. 2010, 155, 695-703. [CrossRef] [PubMed] 